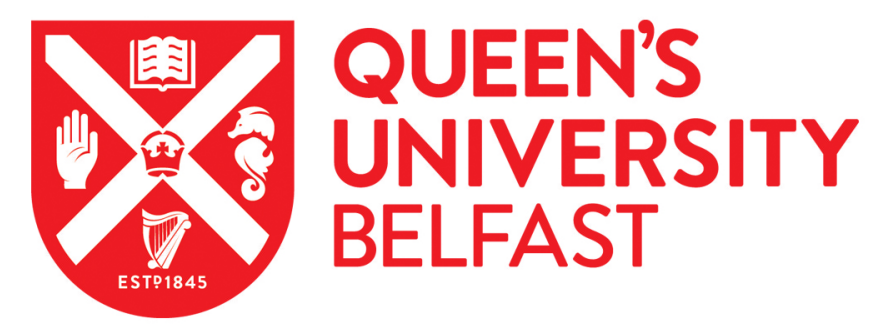

\title{
Radiation responses of stem cells: targeted and not-targeted effects
}

Kavanagh, J. N., Waring, E. J., \& Prise, K. M. (2015). Radiation responses of stem cells: targeted and nottargeted effects. Radiation Protection Dosimetry, 166(1-4), 110-117. https://doi.org/10.1093/rpd/ncv161

\author{
Published in: \\ Radiation Protection Dosimetry
}

Document Version:

Peer reviewed version

Queen's University Belfast - Research Portal:

Link to publication record in Queen's University Belfast Research Portal

Publisher rights

(c) The Author 2015

This is a pre-copyedited, author-produced PDF of an article accepted for publication in Radiation Protection Dosimetry following peer review. The version of record is available online at: http://rpd.oxfordjournals.org/content/166/1-4/110.

\section{General rights}

Copyright for the publications made accessible via the Queen's University Belfast Research Portal is retained by the author(s) and / or other copyright owners and it is a condition of accessing these publications that users recognise and abide by the legal requirements associated with these rights.

Take down policy

The Research Portal is Queen's institutional repository that provides access to Queen's research output. Every effort has been made to ensure that content in the Research Portal does not infringe any person's rights, or applicable UK laws. If you discover content in the Research Portal that you believe breaches copyright or violates any law, please contact openaccess@qub.ac.uk. 


\title{
RADIATION RESPONSES OF STEM CELLS: TARGETED AND NON- TARGETED EFFECTS
}

\author{
J.N. Kavanagh ${ }^{1, *}$, E.J. Waring ${ }^{1 *}$, and K.M. Prise ${ }^{1^{* *}}$ \\ ${ }^{1}$ Centre for Cancer Research and Cell Biology, Queen's University Belfast, 97 Lisburn Road, Belfast BT9 7AE, \\ UK
}

\section{Received, amended, accepted}

Stem cells are fundamental to the development of any tissue or organism via their ability to self-renew, which is aided by their unlimited proliferative capacity and their ability to produce fully differentiated offspring, often from multiple lineages. Stems cells are long lived and have the potential to accumulate mutations, including in response to radiation exposure. It is thought that stem cells have the potential to be induced into a cancer stem cell phenotype and that these may play an important role in resistance to radiotherapy. For radiation-induced carcinogenesis, the role of targeted and non-targeted effects is unclear with tissue or origin being important. Studies of genomic instability and bystander responses have shown consistent effects in haematopoietic models. Several models of radiation have predicted that stem cells play an important role in tumour initiation and that bystander responses could play a role in proliferation and selfrenewal.

\section{STEM CELLS}

The human body originates from a single cell that replicates into around $3.72 \times 10^{13}$ cells ${ }^{(1)}$. In addition to this cells are constantly needed to replace those lost, while also maintaining the proper stratification of organs. Stem cells allow this to be achieved. They possess two key features intrinsic to their role; the first is their ability to self-renew, which is aided by their unlimited proliferative capacity and the second is their ability to produce fully differentiated offspring, often from multiple lineages ${ }^{(2)}$ (see figure 1).

Stem cells can be categorised either by their potency (differential capabilities), or at which stage of

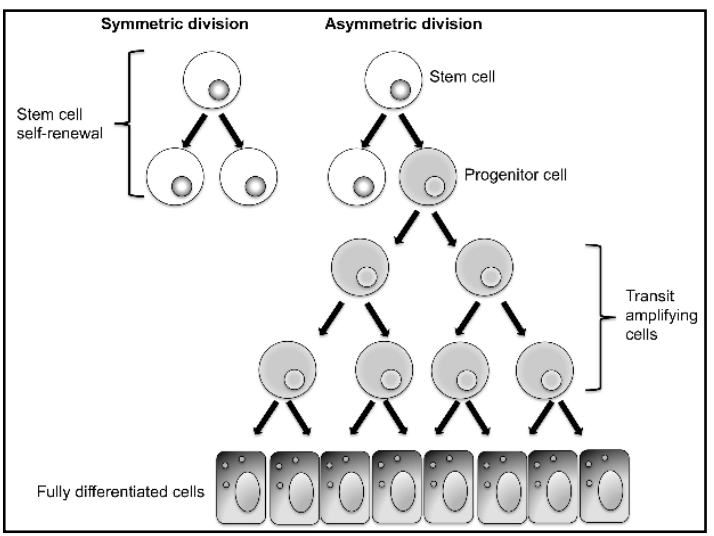

Figure 1. Schematic representation of stem cell self-renewal by symmetric division and provision of progenitor cells by asymmetrical division that ultimately differentiate to yield the mature cells that make the bulk of the tissue. development development they are derived, although these are linked. For example, early embryonic stem cells (ESC) derived from the zygote are totipotent and are able to differentiate into any cell required for the development of a whole organism ${ }^{(3)}$. In comparison, ESCs derived from the inner mass of the blastocyst ${ }^{(3)}$ are able to differentiate into all 3 germ layers of the embryo (ectoderm, mesoderm, endoderm ${ }^{(2)}$ ), but are unable to form placental cells (which are derived from the trophoblast- the outer cell mass of the blastocyst $\left.{ }^{(4)}\right)$, and as such are termed pluripotent ${ }^{(3)}$. Foetal and adult stem cells are either multipotent (capable of multiple differentiated progeny) or unipotent (giving rise to only one type of differentiated progeny). Traditionally both foetal and adult stem cells are thought to have differential capabilities limited to the tissue they reside in ${ }^{(5)}$.

The conventional view of stem cell differentiation can be seen as a hierarchy, with the stem cells at the top, followed by progenitor cells (committed to differentiation with finite proliferative capacity), then transit amplifying cells, and finally differentiated cells $^{(6)}$ - Adult stem cells are usually slowly proliferating as the number of progeny is expanded in the progenitor and transit amplifying divisions ${ }^{(7)}$.

Stem cells can show considerable plasticity, with some cells capable of giving rise to unexpected progeny e.g. adipose stem cells producing osteocytes (although it is not yet clear whether this occurs in vivo). Another challenge to a traditionalist view are satellite cells. Previously categorised as progenitor cells, a fraction of their population have been shown to exhibit stem like properties and replenish the population of satellite cells upon division ${ }^{(8)}$. It has also been recently reported that

**Corresponding author: k.prise@qub.ac.uk

*These authors contributed equally to the work. 


\section{J. N. KAVANAGH, E. J. WARING and K. M. PRISE}

epithelial cells can de-differentiate back to stem cells in progeny can be found in Table 1 vivo ${ }^{(9)}$. A summary of stem cells, their location and

Table 1. Main types of stem cells and lineages of their progeny.

\begin{tabular}{|c|c|c|c|}
\hline Type & Location & Potency & Differentiated Progeny \\
\hline Early Embryonic Stem Cells ${ }^{(3,10)}$ & Zygote & Totipotent & All cells \\
\hline Embryonic Stem Cells (ESC) ${ }^{(\mathbf{3 , 1 1})}$ & Inner cell mass of Blastocyst & Pluripotent & $\begin{array}{l}\text { All } 3 \text { germ layers of an } \\
\text { embryo }\end{array}$ \\
\hline Mesenchymal Stem Cells ${ }^{(12-15)}$ & $\begin{array}{l}\text { Bone Marrow, teeth, peripheral } \\
\text { blood and blood from umbilical } \\
\text { cord, breast tissue }\end{array}$ & Multipotent & $\begin{array}{l}\text { Tenocyte, osteocyte, } \\
\text { myocyte, adipocyte, } \\
\text { chrondrocyte, endothelial } \\
\text { cells. }\end{array}$ \\
\hline Haemapoeitic Stem Cells ${ }^{(\mathbf{1 2}, 13)}$ & $\begin{array}{l}\text { Bone Marrow and peripheral } \\
\text { blood }\end{array}$ & Multipotent & $\begin{array}{l}\text { All blood cell lineages, } \\
\text { myocyte, hepatocyte, } \\
\text { neural stem cell }\end{array}$ \\
\hline Neural Stem Cells ${ }^{(2)}$ & Central nervous system & Multipotent & $\begin{array}{l}\text { Neurons, astrocytes and } \\
\text { oligodendrocytes }\end{array}$ \\
\hline Mammary Stem Cells ${ }^{(\mathbf{1 6})}$ & Breast tissue & Multipotent & $\begin{array}{l}\text { Myoepithelial cells, ductal } \\
\text { epithelial cells, alveolar } \\
\text { epithelial cells }\end{array}$ \\
\hline Intrahepatic ${ }^{(\mathbf{6}, \mathbf{1 7})}$ & Liver & Multipotent & $\begin{array}{l}\text { Hepatocytes, } \\
\text { cholangiocytes and } \\
\text { epithelial cells. }\end{array}$ \\
\hline Adipose $^{(\mathbf{1 8})}$ & Adipose Tissue & Multipotent & $\begin{array}{l}\text { Adipocyte, osteocyte, } \\
\text { chrondrocyte, neurone }\end{array}$ \\
\hline Limbal epithelial $^{(\mathbf{1 9})}$ & Eye (limpal crypts) & Unipotent & Corneal epithelium \\
\hline Lung basal ${ }^{(6,20)}$ & Lung & Multipotent & $\begin{array}{l}\text { Mucosal cells, basal cells } \\
\text { ciliated epithelial cells, } \\
\text { pnemocytes }\end{array}$ \\
\hline Clara cells ${ }^{(20)}$ & Lung & Multipotent & $\begin{array}{l}\text { Clara cells, pnemocytes, } \\
\text { mucous cells, ciliated } \\
\text { epithelial cells, AEC I and } \\
\text { II }\end{array}$ \\
\hline Mucous Cells (20) & Lung & Multipotent & $\begin{array}{l}\text { Basal cell, mucous cells, } \\
\text { ciliated epithelial cells }\end{array}$ \\
\hline Alveolar Epithelial Type II $^{(20)}$ & Lung & Multipotent & AEC I and II \\
\hline Gut epithelial ${ }^{(6)}$ & Gut & Multipotent & $\begin{array}{l}\text { Brush border enterocytes, } \\
\text { paneth cells, goblet cells, } \\
\text { enteroendocrine cells }\end{array}$ \\
\hline Keratinocyte $^{(5,7)}$ & $\begin{array}{l}\text { Basal layer of the epidermis, } \\
\text { Base of the hair follice }\end{array}$ & Multipotent & $\begin{array}{l}\text { Keratinocytes (both skin } \\
\text { and hair) }\end{array}$ \\
\hline Oogonial $^{(21)}$ & Ovaries & Unipotent & Oocyte \\
\hline Spermatagonial ${ }^{(22)}$ & Testes & Unipotent & Spermatozoa \\
\hline Satellite Cells ${ }^{(8,23,24)}$ & Skeletal Muscle & Multipotent & $\begin{array}{l}\text { Myocytes, Adipocytes, } \\
\text { Osteocytes }\end{array}$ \\
\hline
\end{tabular}



Cardiac $^{(25)}$
Heart
Multipotent
Cardiomyocytes, smooth
muscle cells, endothelial
cells

\section{STEM CELLS IN RESEARCH}

Efforts to understand the origins of specialised tissue cells, the role of stem cells in tissue homeostasis and more recently the role of stem cells in cancer have led to the development of sophisticated in vivo model systems and stem cell isolation techniques for ex vivo research. These vary in complexity depending on the stem cell type in question.

One of the most common and useful systems are those that provide information on stem cells function. In other words injection of putative stem cells into the relevant cleared organ results in recapitulation of that functional organ. Ex vivo mouse model examples of this are found for the bone marrow and mammary gland ${ }^{(20,26)}$. Mouse models have also been developed to study lung stem populations. The lung is a highly plastic organ, with $>50 \%$ of epithelial linages exhibiting the stem characteristics of renewal and differentiation, but no single cell capable of differentiating into all lineages (refer to table 1$){ }^{(20,27)}$. As such, mouse lung models often use lineage tracing methods, where cells progeny are marked. This in conjunction with lung injury, to promote proliferation, has been used to identify lung 'stem' populations ${ }^{(20)}$.

Linage tracing in conjunction with inducible transgenic mouse models have been used to study other stem population ${ }^{(28)}$. This technique benefits from the ability to use it in a developing mouse, in comparison to the less valid cleared organ model.

Another strategy is to examine endogenous cells or tissues either in single cell isolates or slices of paraffin embedded tissues, for stem cell markers. Frequently used stem cell markers include bromodeoxyuridine incorporation, Ki67, aldehyde dehyrodenase expression, CD49f, CD133 and CD34. These markers (and others) may also be used to estimate CSC frequencies in tumour biopsies ${ }^{(29-32)}$.

Relative ease of access and depth of study has meant that hematopoietic stem cells are now very well characterised and can be purified relatively quickly using magnetic bead or fluorescent activated cell sorting (FACS) strategies. These strategies have been adapted for analysis and sorting of stem cells from other tissues, although there is much debate over the correct surface antigens to use as markers of stem and committed progenitors, particularly in the breast. As a result of these discrepancies, populations isolated for in vitro experimentation should be checked first for stem cell function using an in vivo model system such as described above. However in vitro models can be very informative as well allowing considerably higher throughput and lower costs than in vivo experiments. Many in vitro systems have been developed to mimic stem cell niche environments that enable these cells to be maintained in culture. These often employ spheroid culture in serum free, non-adherent culture conditions such as those developed by Dontu and co-workers for growth of mammary stem cells ${ }^{(16)}$.

\section{STEM CELLS AND CANCER}

The importance of stem cells and their interrelationships with cancer stem cells (CSCs) in cancer initiation has been an important topic in recent

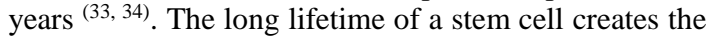
potential for mutations to be acquired, including from ionising radiation (IR), which may lead to the transition into a CSC ${ }^{(35)}$. In addition to this, dedifferentiation of cancer and cancer progenitor cells can produce CSCs $(36,37)$.

The existence of CSCs was inferred from the phenotypic heterogeneity observed within solid tumours ${ }^{(38)}$. As solid tumours are thought to arise from a single cell, this suggests the cell-of-origin may have stem-like qualities. Further evidence came from comparing studies where human CSCs are able to form tumours in immunodeficient mice ${ }^{(30,39,40)}$, but large numbers of non-stem like cancer cells are required for tumour formation ${ }^{(38)}$.

CSCs have been highlighted as critical target populations in cancer therapy, including radiotherapy. Traditional cancer therapies may target the non-stem like bulk of a tumour but leave the small population of more resistant CSCs unaffected ${ }^{(41-43)}$. Residual, treatment-resistant CSCs are the likely cause of tumour recurrence.

\section{RADIATION AND CANCER}

IR is a well-known carcinogen. Epidemiology studies have investigated the effects of population exposures such as the Japanese atomic bomb exposures and nuclear accidents. An increased risk of most types of solid cancer has been reported following these events $(44,45)$. Data from many of these studies supports the linear no-threshold model (LNT) (where risk of cancer is proportional to dose and there is no safe exposure range) $(46,47)$ although there have been reports of a saturation of response at high doses $(44,48)$. Important epidemiological data has also been revealed, for 
example, the role of radioactive contaminated products (such as milk) inducing thyroid cancer in children ${ }^{(49)}$.

Radiation doses can be divided into high (above 5 Gy), moderate (between 0.5 and 5 Gy) and low doses (below $0.5 \mathrm{~Gy})^{(50)}$. Traditionally radiation was thought to cause carcinogenesis through direct DNA damage, in particular the formation of DNA double-strand breaks (DSB). However, other factors such as non-targeted effects (where direct DNA damage is not the main route) (51) such as bystander effects (the influence of irradiated cells on non-irradiated cells) (52) are also likely to affect carcinogenesis, especially at low doses (50). Research into these phenomena has shown for example low dose hypersensitivity, suggesting that the LNT model may not be applicable to low doses.

\section{RADIATION EFFECTS ON STEM CELLS}

A number of groups have attempted to understand the impact of IR directly on early events that may be precursors to carcinogenesis such as DNA damage; proliferation and cell death. The role of IR in transformation of stem cells into CSCs however, is not yet fully understood. Stem cells show modified responses to IR exposure in comparison to differentiated cells, possibly as they have modified DNA repair responses. Tichy et al. (2010) found that murine ESCs favour the homologous recombination (HR) form of DSB repair, over non-homologous end joining (NHEJ) favoured murine embryonic fibroblasts (53). This is likely to be because HR is less error prone, as it requires a template for synthesis of the repaired DNA ${ }^{(53)}$. Despite this, murine ESCs exposed to high doses of IR (5 and $10 \mathrm{~Gy}$ ) show up to a 100-fold increase in mutation rates (measured by loss of heterozygosity of Aprt gene) in comparison to adult fibroblasts, due to an increase in mitotic recombination (54). High doses of IR are known to decrease cell survival, although there are conflicting opinions on whether this is due to apoptosis. Increased senescence (but not apoptosis) has been reported in murine haemopoietic stem cells (HSC) in vivo ${ }^{(55,56)}$, while a study using human mesenchymal stem cells (MSCs) in vitro found 5 Gy $\gamma$-irradiation induced apoptosis ${ }^{(57)}$.

Both high and moderate doses appear to cause cell cycle arrest specifically at G2 rather than G1 $(58,59)$. Moderate doses also cause a wide variety of changes to the transcriptome. These include alterations in genes controlling cell cycle, cell death, transcription, cell morphology, molecular transport, amino acid metabolism, growth factors, and oxidative stress, in addition to cytokine, p53, TGF- $\beta$, and Wnt signalling (60-62). Studies of the effect of IR on stem cell differentiation has produced variable effects, with increased differentiation ${ }^{(61)}$, decreased potency ${ }^{(63)}$ or no effect observed ${ }^{(60)}$. There is also debate as to whether moderate doses induce transcription of apoptosis related genes, with Wilson et al. (2010) reporting an increase in ESCs ${ }^{(60)}$, while Rachidi et al. (2007) found a decrease in human epidermal cells ${ }^{(62)}$. Clonogenic experiments support a decrease in apoptosis, and indicate that stem cells are relatively radio-resistant in comparison to progenitor or differentiated cells $(62,64)$. Some inconsistencies may be due to differences in analysis time after irradiation. Sokolov et al. (2011) found that transcriptomes measured 2 hours after 1 Gy showed a pro-apoptotic response, while 16 hours after they showed an increased pro-survival response ${ }^{(65)}$.

Low dose IR does not appear to cause an increase in cell death $(60,66)$, but increased proliferation has been observed in several studies. Liang et al. (2011) found a significant increase in proliferation of rat MSC at 50 and $75 \mathrm{mGy}{ }^{(67)}$. However, increases in proliferation at $20 \mathrm{mGy}$ and $100 \mathrm{mGy}$ failed to reach significance, indicating a non-linear response ${ }^{(67)}$. In vivo studies have also found increased proliferation, in both HSCs in (75 mGy) ${ }^{(68)}$ and neural stem cells (NSC) (300 mGy) ${ }^{(66)}$. Bakinskis et al. (2011) found an increase in proliferation proteins in murine NSC, but no increase in proliferation rate ${ }^{(69)}$. Wei et al. (2012) suggested that increased proliferation at low doses (300 mGy) was due to an increase in Wnt/ $\beta$-catenin signalling, which was not seen at moderate (3Gy) doses ${ }^{(66)}$. This contradicts Wilson et al. (2010) who found increased Wnt/ $\beta$-catenin signalling in 2 Gy irradiated cells, but not in 400 mGy irradiated cells.

\section{STEM CELLS AND NON-TARGETED RADIATION EFFECTS}

Although there are discrepancies between the reports of

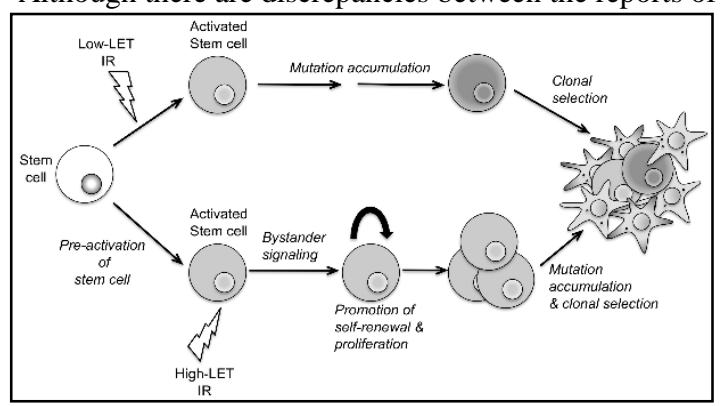

Figure 2. Model of radiation action on stem cells proposed by Shuryak et $a l^{(61)}$. Low LET IR is proposed to contribute to carcinogenesis by initiation of normal tissue stem cells to activated stem cells. Some of those may acquire further mutations and eventually become malignant. Conversely, the role of high LET IR is mainly through promotion of already activated stem cells via bystander signals produced by irradiated cells. 


\section{RADIATION RESPONSES OF STEM CELLS}

different groups, likely due to differences in the time of analysis post IR or model system used, an overview of low dose responses could be suggestive of a nontargeted mechanism, both in vitro and in vivo. In most cases this seems to be a pro-survival affect. These effects have been shown in vivo for normal tissue as well as cancer model systems. Reports of a role of bystander effects on stem cells is also both tissue type and species dependent. Murine mesenchymal stem cells of the bone marrow do not display a bystander effect $(70,71)$ in contrast to HSCs of both mouse and human origin, in which bystander effects and genomic instability have been described (72-74) and in human NSCs, where radiation induced bystander signals induce differentiation ${ }^{(75)}$. In the breast, an increase in the CSC population, compared to sham-irradiated mice, has been observed in Blab/c mice when the stroma was irradiated prior to inoculation of Trp 53 null epithelial cells. In these experiments an increase in tumour formation was also induced by low dose IR of the stroma, $100 \%$ in 10 and 100 mGy-irradiated mice compared to $69 \%$ in sham irradiated mice (76). Suggesting that factors secreted by the stroma activate stem cell self-renewal pathways. An increase in the stem cell population may create a larger target pool from which stem cells carrying mutations may arise. An in vitro investigation of bystander effects in normal HSCs employed a grid that allowed either $100 \%$ or $50 \%$ of cells to be irradiated. These experiments showed that will shielding with the grid resulted in a decrease of cell killing, the frequency of chromosome aberrations was not affected by the grid with 1Gy irradiated cells having 0.135 aberrations per cells compared to 0.132 when $50 \%$ of cells were shielded by the $\operatorname{grid}^{(77)}$.

\section{STEM CELLS AND RADIATION CARCINOGENESIS}

A model describing the distinct roles of low and high LET radiation on stem cells has been proposed and tested in vivo using persistent dysplasia in mouse mammary glands as a positive outcome ${ }^{(78)}$. Figure 2 is a schematic interpretation of that model. That research suggests that low LET IR directly initiates normal stem cells to an activated cell state, in which they are primed to acquire genetic mutations that ultimately lead to a malignant state. This results in a direct dose rate effect at low doses. In contrast, that group proposed that high LET IR contributes to carcinogenesis mainly through a bystander signalling mechanism. In that case a small number of cells are traversed by one or more tracks of densely IR, resulting in secretion of signal molecules that promote proliferation of nearby unirradiated stem cells that have been activated by an earlier event. The risk of carcinogenesis is then decreased as the dose rate increased due to a dominance of cell killing over bystander stimulated promotion.

\section{SUMMARY}

Stem cells are fundamental to normal embryonic development and tissue homeostasis. As such it is not surprising that studies of the DNA damage response of ESCs has shown a strong preference in these cells for the high fidelity form of DNA DSB repair, homologous recombination. This idea is supported by reports in some types of CSCs that they exhibit lower frequencies of DSBs compared to non-stem like cancer cells which is explained by increased ability to scavenge reactive oxygen species and slower DSB repair rate that favours repair by HR ${ }^{(79)}$. Whether similar mechanisms exist in normal adult stem cells remains unclear and future research should be directed at understanding mechanisms that stem cells (other than HSCs) use to deal with mutagenic insults. As long-lived adult stem cells are relatively more quiescent they have been proposed to have an increased propensity to accumulate carcinogenic mutations. In recent years, so called cancer-stem cells have been observed and isolated in many types of human cancers including leukaemia and breast cancer. These cells are so named because they share many traits with normal stem cells most importantly the ability to self-renew. Several researchers have proposed normal adult stem and progenitor cells as the origin of CSCs.

The role of IR and non-targeted radiation effects in the activation of stem cells to a malignant state is unclear. However research in this area shows that whether a stem cell is sensitive or resistant to IR is highly dependent on the tissue of origin. Never the less several models of radiation carcinogenesis predict that stem cells play a major role in tumour initiation. In particular radiation induced bystander signals appear to promote proliferation and self-renewal. Future expansion of this area of research should define the mechanism(s) of action. Although in vitro and ex vivo studies are highly valuable it is clear that in depth in vivo analysis of the impact of IR on normal tissue stem cells is required to understand their role in carcinogenesis.

\section{ACKNOWLEDGEMENTS}

This work was supported by the EU FP7 project EpiRadBio Grant No:269553

\section{REFERENCES}

1. E. Bianconi, A. Piovesan, F. Facchin, et al. An estimation of the number of cells in the human body. Ann.Hum.Biol. (2013) 
2. B. R. Yi, S. U. Kim and K. C. Choi. Development and application of neural stem cells for treating various human neurological diseases in animal models. Lab.Anim.Res. 29, 131-137 (2013)

3. T. Ishiuchi and M. E. Torres-Padilla. Towards an understanding of the regulatory mechanisms of totipotency. Curr.Opin.Genet.Dev. 23, 512-518 (2013)

4. A. M. Sharkey and N. S. Macklon. The science of implantation emerges blinking into the light. Reprod.Biomed.Online. 27, 453-460 (2013)

5. H. M. Blau, T. R. Brazelton and J. M. Weimann. The evolving concept of a stem cell: entity or function? Cell. 105, 829-841 (2001)

6. M. Korbling and Z. Estrov. Adult stem cells for tissue repair - a new therapeutic concept? N.Engl.J.Med. 349, 570-582 (2003)

7. J. M. Slack. Stem cells in epithelial tissues. Science. 287, 1431-1433 (2000)

8. J. S. Kang and R. S. Krauss. Muscle stem cells in developmental and regenerative myogenesis. Curr.Opin.Clin.Nutr.Metab.Care. 13, 243-248 (2010)

9. P. R. Tata, H. Mou, A. Pardo-Saganta, et al. Dedifferentiation of committed epithelial cells into stem cells in vivo. Nature. (2013)

10. S. M. Morgani, M. A. Canham, J. Nichols, et al. Totipotent embryonic stem cells arise in ground-state culture conditions. Cell.Rep. 3, 1945-1957 (2013)

11. G. R. Martin. Isolation of a pluripotent cell line from early mouse embryos cultured in medium conditioned by teratocarcinoma stem cells. Proc.Natl.Acad.Sci.U.S.A. 78, 7634-7638 (1981)

12. M. Esrefoglu. Role of stem cells in repair of liver injury: Experimental and clinical benefit of transferred stem cells on liver failure. World J.Gastroenterol. 19, 6757-6773 (2013)

13. J. Oswald, S. Boxberger, B. Jorgensen, et al. Mesenchymal stem cells can be differentiated into endothelial cells in vitro. Stem Cells. 22, 377-384 (2004)

14. J. Hua, J. Gong, H. Meng, et al. Comparison of different methods for the isolation of mesenchymal stem cells from umbilical cord matrix: proliferation and multilineage differentiation as compared to mesenchymal stem cells from umbilical cord blood and bone marrow. Cell Biol.Int. (2013)

15. C. Zhang, W. Zhai, Y. Xie, Q. Chen, W. Zhu and $X$. Sun. Mesenchymal stem cells derived from breast cancer tissue promote the proliferation and migration of the MCF-7 cell line. Oncol.Lett. 6, 1577-1582 (2013)

16. G. Dontu, W. M. Abdallah, J. M. Foley, et al. In vitro propagation and transcriptional profiling of human mammary stem/progenitor cells. Genes Dev. $17,1253-1270$ (2003)
17. A. Conigliaro, D. A. Brenner and T. Kisseleva. Hepatic progenitors for liver disease: current position. Stem Cells Cloning. 3, 39-47 (2010)

18. B. Lindroos, R. Suuronen and S. Miettinen. The potential of adipose stem cells in regenerative medicine. Stem Cell.Rev. 7, 269-291 (2011)

19. H. J. Levis, I. Massie, M. A. Dziasko, A. Kaasi and J. T. Daniels. Rapid tissue engineering of biomimetic human corneal limbal crypts with 3D niche architecture. Biomaterials. 34, 8860-8868 (2013)

20. X. Liu, R. R. Driskell and J. F. Engelhardt. Stem cells in the lung. Methods Enzymol. 419, 285-321 (2006)

21. D. C. Woods and J. L. Tilly. Isolation, characterization and propagation of mitotically active germ cells from adult mouse and human ovaries. Nat.Protoc. 8, 966-988 (2013)

22. Y. Guo, Y. Hai, Y. Gong, Z. Li and Z. He. Characterization, isolation and culture of mouse and human spermatogonial stem cells. J.Cell.Physiol. (2013)

23. J. C. Chen and D. J. Goldhamer. Skeletal muscle stem cells. Reprod.Biol.Endocrinol. 1, 101 (2003)

24. Maturen KE, Feng MU, Wasnik AP, et al. Imaging effects of radiation therapy in the abdomen and pelvis: evaluating "innocent bystander" tissues. Radiographics : a review publication of the Radiological Society of North America, Inc. 33, 599-619 (2013)

25. L. Barile, E. Messina, A. Giacomello and E. Marban. Endogenous cardiac stem cells. Prog.Cardiovasc.Dis. 50, 31-48 (2007)

26. I. Illa-Bochaca, R. Fernandez-Gonzalez, D. N. Shelton, B. E. Welm, C. Ortiz-de-Solorzano and M. H. Barcellos-Hoff. Limiting-dilution transplantation assays in mammary stem cell studies. Methods Mol.Biol. 621, 29-47 (2010)

27. D. N. Kotton and E. E. Morrisey. Lung regeneration: mechanisms, applications and emerging stem cell populations. Nat.Med. 20, 822-832 (2014)

28. A. C. Rios, N. Y. Fu, G. J. Lindeman and J. E. Visvader. In situ identification of bipotent stem cells in the mammary gland. Nature. 506, 322-327 (2014)

29. S. K. Singh, I. D. Clarke, M. Terasaki, et al. Identification of a cancer stem cell in human brain tumors. Cancer Res. 63, 5821-5828 (2003)

30. C. A. O'Brien, A. Pollett, S. Gallinger and J. E. Dick. A human colon cancer cell capable of initiating tumour growth in immunodeficient mice. Nature. 445, 106-110 (2007)

31. M. Al-Hajj, M. S. Wicha, A. Benito-Hernandez, S. J. Morrison and M. F. Clarke. Prospective identification of tumorigenic breast cancer cells. Proc.Natl.Acad.Sci.U.S.A. 100, 3983-3988 (2003)

32. D. Bonnet and J. E. Dick. Human acute myeloid leukemia is organized as a hierarchy that originates 


\section{RADIATION RESPONSES OF STEM CELLS}

from a primitive hematopoietic cell. Nat.Med. 3, 730737 (1997)

33. M. S. Wicha, S. Liu and G. Dontu. Cancer stem cells: an old idea--a paradigm shift. Cancer Res. 66, 1883-90; discussion 1895-6 (2006)

34. S. Sell. On the stem cell origin of cancer. Am.J.Pathol. 176, 2584-2494 (2010)

35. K. M. Prise and A. Saran. Concise review: stem cell effects in radiation risk. Stem Cells. 29, 1315-1321 (2011)

36. B. Das, R. Tsuchida, D. Malkin, G. Koren, S. Baruchel and $H$. Yeger. Hypoxia enhances tumor stemness by increasing the invasive and tumorigenic side population fraction. Stem Cells. 26, 1818-1830 (2008)

37. N. Charles, T. Ozawa, M. Squatrito, et al. Perivascular nitric oxide activates notch signaling and promotes stem-like character in PDGF-induced glioma cells. Cell.Stem Cell. 6, 141-152 (2010)

38. N. A. Lobo, Y. Shimono, D. Qian and M. F. Clarke. The biology of cancer stem cells. Annu.Rev.Cell Dev.Biol. 23, 675-699 (2007)

39. T. Lapidot, C. Sirard, J. Vormoor, et al. A cell initiating human acute myeloid leukaemia after transplantation into SCID mice. Nature. 367, 645-648 (1994)

40. S. K. Singh, C. Hawkins, I. D. Clarke, et al. Identification of human brain tumour initiating cells. Nature. 432, 396-401 (2004)

41. R. Pardal, M. F. Clarke and S. J. Morrison. Applying the principles of stem-cell biology to cancer. Nat.Rev.Cancer. 3, 895-902 (2003)

42. R. J. Gilbertson and T. A. Graham. Cancer: Resolving the stem-cell debate. Nature. 488, 462-463 (2012)

43. F. Tomao, A. Papa, L. Rossi, et al. Emerging role of cancer stem cells in the biology and treatment of ovarian cancer: basic knowledge and therapeutic possibilities for an innovative approach. J.Exp.Clin.Cancer Res. 32, 48-9966-32-48 (2013)

44. D. L. Preston, E. Ron, S. Tokuoka, et al. Solid cancer incidence in atomic bomb survivors: 1958-1998. Radiat.Res. 168, 1-64 (2007)

45. M. P. Little. Cancer and non-cancer effects in Japanese atomic bomb survivors. J.Radiol.Prot. 29, A43-59 (2009)

46. C. E. Land, M. Tokunaga, K. Koyama, et al. Incidence of female breast cancer among atomic bomb survivors, Hiroshima and Nagasaki, 1950-1990. Radiat.Res. 160, 707-717 (2003)

47. C. M. Ronckers, C. A. Erdmann and C. E. Land. Radiation and breast cancer: a review of current evidence. Breast Cancer Res. 7, 21-32 (2005)

48. D. L. Preston, A. Mattsson, E. Holmberg, R. Shore, N. G. Hildreth and J. D. Boice Jr. Radiation effects on breast cancer risk: a pooled analysis of eight cohorts. Radiat.Res. 158, 220-235 (2002)

49. S. Fushiki. Radiation hazards in children - lessons from Chernobyl, Three Mile Island and Fukushima. Brain Dev. 35, 220-227 (2013)

50. M. Kadhim, S. Salomaa, E. Wright, et al. Nontargeted effects of ionising radiation-Implications for low dose risk. Mutat.Res. 752, 84-98 (2013)

51. W. F. Morgan and M. B. Sowa. Effects of ionizing radiation in nonirradiated cells. Proc.Natl.Acad.Sci.U.S.A. 102, 14127-14128 (2005)

52. B. J. Blyth and P. J. Sykes. Radiation-induced bystander effects: what are they, and how relevant are they to human radiation exposures? Radiat.Res. 176, 139-157 (2011)

53. E. D. Tichy, R. Pillai, L. Deng, et al. Mouse embryonic stem cells, but not somatic cells, predominantly use homologous recombination to repair double-strand DNA breaks. Stem Cells Dev. 19, 16991711 (2010)

54. N. G. Denissova, I. V. Tereshchenko, E. Cui, P. J. Stambrook, C. Shao and J. A. Tischfield. Ionizing radiation is a potent inducer of mitotic recombination in mouse embryonic stem cells. Mutat.Res. 715, 1-6 (2011)

55. Y. Wang, L. Liu, S. K. Pazhanisamy, H. Li, A. Meng and D. Zhou. Total body irradiation causes residual bone marrow injury by induction of persistent oxidative stress in murine hematopoietic stem cells. Free Radic.Biol.Med. 48, 348-356 (2010)

56. Y. Wang, L. Liu and D. Zhou. Inhibition of p38 MAPK attenuates ionizing radiation-induced hematopoietic cell senescence and residual bone marrow injury. Radiat.Res. 176, 743-752 (2011)

57. T. M. Filion, M. Qiao, P. N. Ghule, et al. Survival responses of human embryonic stem cells to DNA damage. J.Cell.Physiol. 220, 586-592 (2009)

58. Y. Hong and P. J. Stambrook. Restoration of an absent G1 arrest and protection from apoptosis in embryonic stem cells after ionizing radiation. Proc.Natl.Acad.Sci.U.S.A. 101, 14443-14448 (2004)

59. O. Momcilovic, S. Choi, S. Varum, C. Bakkenist, G. Schatten and C. Navara. Ionizing radiation induces ataxia telangiectasia mutated-dependent checkpoint signaling and $G(2)$ but not $G(1)$ cell cycle arrest in pluripotent human embryonic stem cells. Stem Cells. 27, 1822-1835 (2009)

60. K. D. Wilson, N. Sun, M. Huang, et al. Effects of ionizing radiation on self-renewal and pluripotency of human embryonic stem cells. Cancer Res. 70, 55395548 (2010)

61. S. Monzen, E. Tashiro and I. Kashiwakura. Megakaryocytopoiesis and thrombopoiesis in hematopoietic stem cells exposed to ionizing radiation. Radiat.Res. 176, 716-724 (2011) 
62. W. Rachidi, G. Harfourche, G. Lemaitre, F. Amiot, P. Vaigot and M. T. Martin. Sensing radiosensitivity of human epidermal stem cells. Radiother.Oncol. 83, 267276 (2007)

63. N. Hayashi, S. Monzen, K. Ito, T. Fujioka, Y. Nakamura and I. Kashiwakura. Effects of ionizing radiation on proliferation and differentiation of mouse induced pluripotent stem cells. J.Radiat.Res. 53, 195201 (2012)

64. F. P. D'Andrea, M. R. Horsman, M. Kassem, J. Overgaard and A. Safwat. Tumourigenicity and radiation resistance of mesenchymal stem cells. Acta Oncol. 51, 669-679 (2012)

65. M. V. Sokolov, I. V. Panyutin, I. G. Panyutin and R. D. Neumann. Dynamics of the transcriptome response of cultured human embryonic stem cells to ionizing radiation exposure. Mutat.Res. 709-710, 40-48 (2011)

66. L. C. Wei, Y. X. Ding, Y. H. Liu, et al. Low-dose radiation stimulates Wnt/beta-catenin signaling, neural stem cell proliferation and neurogenesis of the mouse hippocampus in vitro and in vivo. Curr.Alzheimer Res. 9, 278-289 (2012)

67. X. Liang, Y. H. So, J. Cui, et al. The low-dose ionizing radiation stimulates cell proliferation via activation of the MAPK/ERK pathway in rat cultured mesenchymal stem cells. J.Radiat.Res. 52, 380-386 (2011)

68. W. Li, G. Wang, J. Cui, L. Xue and L. Cai. Lowdose radiation (LDR) induces hematopoietic hormesis: LDR-induced mobilization of hematopoietic progenitor cells into peripheral blood circulation. Exp.Hematol. 32, 1088-1096 (2004)

69. A. Bajinskis, H. Lindegren, L. Johansson, M. Harms-Ringdahl and A. Forsby. Low-dose/dose-rate gamma radiation depresses neural differentiation and alters protein expression profiles in neuroblastoma $\mathrm{SH}$ SY5Y cells and C17.2 neural stem cells. Radiat.Res. 175, 185-192 (2011)

70. M. V. Sokolov and R. D. Neumann. Radiationinduced bystander effects in cultured human stem cells. PLoS One. 5, e14195 (2010)
71. J. Gomez-Millan, I. S. Katz, A. Farias Vde, et al. The importance of bystander effects in radiation therapy in melanoma skin-cancer cells and umbilicalcord stromal stem cells. Radiother.Oncol. 102, 450-458 (2012)

72. D. A. Bowler, S. R. Moore, D. A. Macdonald, S. H. Smyth, P. Clapham and M. A. Kadhim. Bystandermediated genomic instability after high LET radiation in murine primary haemopoietic stem cells. Mutat.Res. 597, 50-61 (2006)

73. S. A. Lorimore, D. Mukherjee, J. I. Robinson, J. A. Chrystal and E. G. Wright. Long-lived inflammatory signaling in irradiated bone marrow is genome dependent. Cancer Res. 71, 6485-6491 (2011)

74. H. Shen, H. Yu, P. H. Liang, et al. An acute negative bystander effect of gamma-irradiated recipients on transplanted hematopoietic stem cells. Blood. 119, 3629-3637 (2012)

75. A. Ozeki, K. Suzuki, M. Suzuki, H. Ozawa and S. Yamashita. Acceleration of astrocytic differentiation in neural stem cells surviving $X$-irradiation. Neuroreport. 23, 290-293 (2012)

76. D. H. Nguyen, H. A. Oketch-Rabah, I. IllaBochaca, et al. Radiation acts on the microenvironment to affect breast carcinogenesis by distinct mechanisms that decrease cancer latency and affect tumor type. Cancer.Cell. 19, 640-651 (2011)

77. S. A. Lorimore, M. A. Kadhim, D. A. Pocock, et al. Chromosomal instability in the descendants of unirradiated surviving cells after alpha-particle irradiation. Proc.Natl.Acad.Sci.U.S.A. 95, 5730-5733 (1998)

78. I. Shuryak, D. J. Brenner and R. L. Ullrich. Radiation-induced carcinogenesis: mechanistically based differences between gamma-rays and neutrons, and interactions with DMBA. PLoS One. 6, e28559 (2011)

79. F. Pajonk, E. Vlashi and W. H. McBride. Radiation resistance of cancer stem cells: the 4 R's of radiobiology revisited. Stem Cells. 28, 639-648 (2010) 